\title{
Higher education in turbulent times: A geographical perspective
}

\author{
Lecture in Geography \\ read 5 June 2018 \\ MERIC S. GERTLER \\ Fellow of the Academy
}

Abstract: Two major trends pose unprecedented challenges to higher education. A backlash against globalisation has fuelled protectionism, nativism, and inward-looking national politics. And confidence in higher education institutions is declining. Research universities are uniquely able to address both challenges if they embrace new strategic directions, globally and locally. They must leverage their global networks and foster research collaboration to overcome parochialism and address grand challenges. They must commit to strengthening their local communities or urban regions and ensure access for students from the widest range of socio-economic backgrounds. These strategies will better position universities to secure the broad public support they need to thrive.

Keywords: university, globalisation, research, community, urban, socio-economic, public, access, geography.

\section{INTRODUCTION}

To say that we live in turbulent times is an understatement.

In many countries, a growing backlash against the impact of globalisation is prompting a resurgence of nativism, protectionism, and an increasingly inward-looking focus to national politics. There are many plausible explanations of this phenomenon. But there is an emerging consensus that it is linked to wider economic and social forces. Chief among these are the growing divides that have come to characterise our 'winner-take-all' economies.

At times of growing economic uncertainty and social disruption, one might expect our institutions of higher education and advanced research to play a leading role in helping us make sense of such trends, and in identifying workable solutions to 
these challenges. In other words, during such periods of immense social and economic upheaval, universities ought to be (and be seen to be) advancing economic prosperity, social cohesion, and inclusivity, and both local and global well-being. It is all the more perplexing, then, that confidence in our institutions of higher education appears to be waning seriously, with their leadership under siege in many quarters. To those who, like me, have devoted the bulk of their working lives to the cause of higher education, this is a profoundly disturbing development.

How should universities respond to such challenges? There seems to be no shortage of advice being directed our way. Indeed, it seems like 'open season' on higher education, with all sorts of pundits and presumed experts offering all manner of prescriptions.

I believe that universities are uniquely well qualified to address both of these challenges - the rise of nativist parochialism and declining confidence in institutions of higher education. In my view, the key to doing so rests on embracing strategic directions that are intentionally geographical.

Universities must leverage their global networks and foster international research collaboration, as an antidote to growing parochialism and as a means to address grand challenges whose scope and complexity transcend national borders. Universities must also embrace their mission of strengthening the local communities in which they are situated. As part of this strategy, they must redouble their commitment to ensuring access to higher education for students from the widest range of socio-economic backgrounds.

By pursuing these two strategic objectives, universities will —I believe - be better positioned to secure the kind of broad public support they require in order to thrive. And in the process, they will also be making themselves stronger.

\section{BACKLASH AGAINST GLOBALISATION}

A popular movement to retreat from international engagement appears to be gaining momentum in many corners of the globe. The Brexit campaign in the United Kingdom is a clear example. More than 17 million people, 52 per cent of the electorate, voted to sever Britain's ties with the European Union, a region representing half a billion people and, at just over a fifth of global GDP, the world's third largest economy. Whatever one's views on Brexit, the vote has been read by many as a reaction against international engagement, and an apparent movement to build barriers between countries instead of bridges. ${ }^{1}$ The resulting political, economic, and social uncertainty in the UK has been well documented. ${ }^{2}$

\footnotetext{
${ }^{1}$ See, for example, Tammes (2017), Becker et al. (2017), and Toly (2016).

${ }^{2}$ See, for example, Giles (2017), Jackson et al. (2017), and Allen (2016).
} 
Recently, it has begun to appear as through Brexit was more of a bellwether than an outlier, as populist, protectionist, and nativist movements have found traction across Europe. According to bookmaker William Hill in May 2018, Denmark, the Czech Republic, Ireland, Hungary, France, Sweden, Italy, and Greece all had better odds of leaving the European Union than Arsenal had (at 20:1) of winning the Premier League in 2019. ${ }^{3}$

Meanwhile, in the United States, nearly 63 million Americans voted to elect Donald Trump as President, after he campaigned successfully on a nativist, Americafirst, anti-immigration, and isolationist vision of America's future. Since his election, we have seen executive orders restricting immigration from certain predominantly Muslim countries; a call for proposals to build a 'big, beautiful wall' along the USMexico border; recurrent threats to the DACA (Deferred Action for Childhood Arrivals) programme; budget proposals calling for increases in military spending and cuts to international aid; the imposition of new trade tariffs; an uncertain fate for the Trans-Pacific Partnership and NAFTA; withdrawal from the Paris Climate Agreement and the Iran deal ... the list goes on.

The United States and the United Kingdom are by no means the only examples I could point to. Similar dynamics are evident in Russia, Turkey, Poland, Australia, and elsewhere.

Major forces appear to be moving us away from mutual trust, cooperation, and international engagement. Many attribute this to the increasingly polarising tendencies of current economic change, in which returns to the most highly educated and talented members of our society are rapidly outstripping the earnings of everyone else, at an accelerating pace.

Whatever its origins, the backlash against globalisation and international engagement has important ramifications for higher education and advanced research. The most obvious consequence might be a long-term decline in the ability to attract and retain globally mobile talent, whether students or faculty. For institutions, whose success depends on openness and the ability to attract top minds from across the country and around the world, this is an existential threat.

The flow of international students seems to be particularly sensitive to changing social attitudes - and regulatory regimes. The US Council of Graduate Schools reports that the number of applications from international students for graduate study at US universities has fallen for the first time in a decade. ${ }^{4}$ The National Science Foundation and others reported an average decline in international applications of

${ }^{3}$ See: http://sports. williamhill.com/bet/en-ca/betting/y/12/Politics.html. The odds were current as of May 2018.

${ }^{4}$ Okahana \& Zhou (2017). 
between 6 and 7 per cent across all disciplines, at both the graduate and undergraduate levels. ${ }^{5}$ The decline is most keenly felt in less selective colleges, master's-level and associates-level institutions, and universities in the Midwest-where 2018 saw particularly steep declines in new international enrolments. ${ }^{6}$

This trend has many profound implications. For example, The New York Times recently reported that new international enrolment at the University of Central Missouri dropped by more than 60 per cent in 2017, at an annual cost to the institution of $\$ 14$ million. $^{7}$ And in December 2017, Moody's lowered its credit outlook for US universities from 'stable' to 'negative', at least in part reflecting the general decline in applications from international students. ${ }^{8}$

Many factors undeniably affect the international flow of talent. But in the case of the US, aggressive and unwelcoming rhetoric from the White House has undoubtedly had an impact. Such rhetoric, and the accompanying policies and executive orders, are also having a negative effect on US institutions' ability to attract and retain highlyskilled faculty. For example, Professor Alán Aspuru-Guzik, a leading scholar of theoretical and computational chemistry, and of Mexican-American origin, recently announced he was leaving his tenured position at Harvard to move to the University of Toronto. To be sure, he was attracted by the opportunities to collaborate with U of T's world-class scholars in chemistry, advanced computing, and machine learning. And the offer of a generously funded Canada 150 Research Chair paved the way. But he also singled out Canada's - and especially Toronto's - welcoming inclusivity and cultural diversity as decisive factors in his decision to move his family from Boston.

In the UK, the Brexit vote seems to have had a different effect on international applications to higher education institutions, at least in the short term. While applications from domestic students declined in 2017, applications from non-UK EU students and non-EU international students grew substantially. Consequently, international applications to British universities topped 100,000 for the first time. ${ }^{9}$ Initially, this might seem surprising, given the anti-foreigner message implied by the Brexit vote. But many UK institutions have apparently recruited international students more aggressively in recent years, though to what degree and at what cost are hotly debated and divisive questions. ${ }^{10}$

Further, some speculate that the recent surge in EU enrolment at UK universities reflects, as The Guardian put it, 'a last-minute rush to study at British universities

\footnotetext{
${ }^{5}$ See, for example, National Science Board (2018).

${ }^{6}$ Zong \& Batalova (2018).

${ }^{7}$ Saul (2018).

${ }^{8}$ Moody's Investors Service (2017).

${ }^{9}$ ICEF Monitor (2018).

${ }^{10}$ For a sense of the debate, see Gilligan (2017) and Attwool (2017).
} 
before Brexit closes the door'. EU enrolment in Britain after the door closes will depend on the resolution of a host of thorny issues, including, among others: student mobility through Erasmus+ and other programmes; the UK's status with respect to Horizon 2020 and its successor, the EU Framework Programme for Research and Innovation; and specific guidelines concerning residency, employment, post-study work visas, and professional qualifications. Much of this remains uncertain-and international students do not typically flock to uncertainty.

In Britain, as in the United States, a decline in international enrolment would have considerable financial implications. A Universities UK study from March 2017 found that 'on- and off-campus spending by international students and their visitors generated $£ 25.8$ billion in gross output for the UK economy'. ${ }^{11}$

Let me now say something about the second trend, the waning confidence in higher education.

\section{WANING CONFIDENCE IN HIGHER EDUCATION}

Higher education seems to be in retreat, and its leaders under siege, on both sides of the Atlantic. Two recent polls in the United States held stark news for American universities and colleges. According to a 2017 Gallup survey, 'While a majority of Democrats and Democratic-leaning independents (56 per cent) say they have a great deal or quite a lot of confidence in colleges, only a third of Republicans and Republicanleaning independents ( 33 per cent) hold that same view. ${ }^{12}$

The Pew Research Center noted similar results (also in 2017). They found 58 per cent of Republicans saying that 'colleges and universities have a negative effect on the way things are going in the country' - that's up from 37 per cent just two years ago. While the views among Democrats are more favourable, these too have suffered a decline in recent years. ${ }^{13}$

It is clear that US higher education is facing some major image challenges. And recall that, when these surveys were conducted (before the 2018 mid-term elections), the Republicans controlled both the executive and legislative branches of the federal government, along with two thirds of state governorships. President Trump's original budget proposal contained several punitive tax measures for university students that were ultimately dropped. But it did eventually include a 1.4 per cent tax on endowment

\footnotetext{
${ }^{11}$ Universities UK (2017a).

${ }^{12}$ Auter (2017).

${ }^{13}$ Fingerhut (2017).
} 
income for private universities with the largest endowments - any institution with endowments exceeding $\$ 500,000$ per student. It is hard to see this as anything but a gesture of contempt for the nation's most elite universities.

Frank Bruni of The New York Times recently quoted Ron Daniels, President of Johns Hopkins University, as saying: 'Even if we were unblemished in our mission, it would be hard to imagine that in Trump's America, we wouldn't be targets for scorn. ${ }^{14}$

And, as Daniels and others would be first to admit, most US universities are not unblemished - especially when it comes to access. A 2011 study cited by Bruni found that many US institutions exhibit a profound and enduring lack of socio-economic diversity. Yale and Princeton, for example, 'had more students from families in the top 1 percent of income than students from families in the bottom 60 percent.'

Moreover, this pattern is not confined to the elite private US institutions. The New York Times compiles an annual College Access Index that includes the share of an institution's undergraduate students who receive federal Pell Grants because of their financial need (typically the bottom half of the income distribution). Data from the most recent year show a disturbing decline among public universities - the very institutions that have traditionally offered the most promising opportunities for social mobility for students of modest family means. Some of the largest declines were in the University of California system, with UC San Diego dropping from 46 per cent in 2011 to 26 per cent in 2017. At the system's flagship campuses - Berkeley and UCLAthe Pell Grant percentages now stand at 22 and 26 per cent, respectively. ${ }^{15}$

Cause and effect are difficult to disentangle here. State support for universities has declined in many public systems across the US, often leading to increasing tuition fees. In 2017, for the first time in history, funding from tuition fees made up a larger share of public university budgets than state appropriations, in more than half of all states in the union. Adjusted for inflation, average per-student state funding for US public universities is about $\$ 2,000$ below its level at the turn of the millennium. ${ }^{16}$

Declining confidence in public universities may help explain why public financial support to institutions has declined so consistently over the past few years. ${ }^{17}$ But the concomitant increase in tuition fees, and the growing tendency to admit more students who can afford to pay the full price, has in turn undermined the reputation of public universities as engines of social mobility. And this vicious circle has likely contributed still further to the subsequent decline in public financial support.

Turning to the United Kingdom, recent public discourse has not been kind to the

\footnotetext{
${ }^{14}$ Bruni (2017).

${ }^{15}$ Leonhardt (2017).

${ }^{16}$ State Higher Education Executive Officers Association (2018).

${ }^{17}$ Auter (2017) notes that, particularly among Democrats, concern over the rising cost of tuition fees is one of the primary factors eroding their confidence in higher education.
} 
nation's universities: the extended furore over vice-chancellor's salaries; an open row between university leadership and government politicians; survey data showing that only 35 per cent of students find their university educations to be 'good' or 'very good' value for money - the lowest level ever ${ }^{18}$ a very public and often heated contest over free speech and political correctness (an issue, incidentally, that has boiled over in the United States and Canada as well); ${ }^{19}$ a lengthy and bitter national strike, occasioned in part by the government's handling of pensions and its perceived encroachment on university autonomy; and a fractious debate over tuition fees, student debt, and access.

On that last point, data from the UK show that leading British universities are as guilty of socio-economic elitism as their US peers. The Higher Education Policy Institute recently published a policy note by Professor Iain Martin called 'Benchmarking Widening Participation: How Should We Measure and Report Progress? ${ }^{20}$ The study looked at participation by local areas using POLAR (Participation of Local Areas) data, and measured inequality by using the Gini index. The results were not very flattering for the Russell Group, whose members accounted for ten of the fifteen lowest scoring - that is, least economically diverse - institutions. In 2016, the University of Cambridge was the least economically diverse university in the United Kingdom: a greater share of its entering class came from the highest socio-economic quintile than from the other four combined, even when adjusting for differences in the population size of the quintiles.

As Nigel Thrift has recently written:

there is a job to be done to shift the scandalous levels of inequality that these institutions help to perpetuate, since the majority of students from low-income families never apply to them in the first place and are concentrated in other higher education institutions by default - the so-called 'undermatching' issue that is really a cover for exclusion. $^{21}$

The litany of challenges facing UK universities is truly extraordinary; how far the mighty appear to have fallen.

At times like these, a bit of perspective is perhaps helpful. As that self-proclaimed Anglophile, Bill Bryson, wrote in The Road to Little Dribbling in 2015:

I very much doubt if there is any other realm of human endeavour in the country that produces more world-class benefit with less financial input than higher education. It is possibly the single most outstanding thing in Britain today.

\footnotetext{
${ }^{18}$ Neves \& Hillman (2017).

${ }^{19}$ Both Bruni (2017) and Auter (2017) single this out as a significant factor undermining public confidence in higher education, particularly among those self-identifying as politically conservative.

${ }^{20}$ Martin (2018).

${ }^{21}$ Thrift (2016: 411).
} 
Building on Bryson's colourful analysis and bringing it up to date, one way to quantify the idea of 'world-class benefit for less financial input' is to note that, by my calculation, not a single university in the UK would qualify for the new US endowment tax because their endowments per student are so low. (Incidentally, no university in Canada would qualify either.) In fact, in 2016, 35 US universities each generated more than $\$ 100$ million in revenue from their sports programmes alone. Only thirteen universities in all of the United Kingdom had entire endowments valued at more than $\$ 100$ million..$^{22}$ And yet, depending on the ranking one chooses, the UK boasts three or four of the world's top ten universities, and as many as 30 in the top 200.

\section{WHAT ARE UNIVERSITIES FOR? FOSTERING GLOBAL AND LOCAL LEADERSHIP}

Apart from Bryson's ode to the remarkable quality of British universities, the story I have told so far is both disconcerting and pessimistic. A backlash against globalisation is turning many nations inward, with many worrisome consequences, not least for higher education. Public confidence in higher education seems to be eroding, threatening the mandates of universities - especially public universities - in the UK, the United States, and beyond.

Amid this doom and gloom, are there any grounds for optimism? I think so, if we are able to leverage the important role that universities can play in advancing our collective prosperity. After all, at a time of profound transformations in labour markets and business models in many sectors of the economy, the core mission of universities to produce talented and resilient graduates, and to undertake path-breaking research has never been more important.

Indeed, despite popular perceptions, the education dividend or wage premium is well established, even in an age of rising tuition fees and student debt. The US Bureau of Labor Statistics reports that in 2017, the average unemployment rate for the population 25 and over was nearly twice as high for those with just a high-school diploma as it was for those with at least a bachelor's degree. ${ }^{23}$ And median weekly earnings were at least 65 per cent higher for the university graduate.

Moreover, these economic advantages are more widely appreciated than we have been led to believe. A 2017 US survey found that an overwhelming majority ( 83 per cent)

\footnotetext{
${ }_{22}^{22}$ Data from the US Department of Education's Equity in Athletics Data Analysis. Data accessed May 2018 at https://ope.ed.gov/athletics/\#/. Additional analysis by the University of Toronto.

${ }^{23}$ Civilian, non-institutional population. 1.5 per cent for doctoral and professional degree holders, 2.2 per cent for master's degree holders, and 2.5 per cent for bachelor's degree holders versus 4.6 per cent for high-school only (Bureau of Labor Statistics 2018).
} 
of parents of public school students expected their children to attend college or university. ${ }^{24}$ The Millennium Cohort Survey found similar results in the UK, where nearly 80 per cent of parents think it likely or very likely that their children will attend university. ${ }^{25}$ And according to the Futuretrack project from the Warwick Institute for Employment Research, ' $96 \%$ of graduates said that with hindsight, they would still go into HE again. ${ }^{26}$

Clearly, notwithstanding the frequent declarations in popular media of the declining value of a university education, the economic case still appears to be sound. But that alone may not be sufficient to convince policy makers, the media, and the wider public of the social value of universities in today's turbulent world.

What else needs to be done? Let me suggest two strategies.

The first of these centres on taking advantage of the global reach of universities, while the second deepens universities' local engagement. In both cases, the goal is for universities to utilise their geographical footprint for the benefit of the host communities and nations in which they are situated. My argument is that, by doing so, they are more likely to regain the public support they have recently lost, while also helping themselves directly.

\section{LEVERAGING GLOBAL NETWORKS}

First, universities must leverage their global networks and foster deeper international research collaborations, both as a means to address global grand challenges and to counter growing parochialism. Universities are gateways to expansive international academic communities. Over the past 25 years, international research collaboration and co-publication have exploded. While the total number of research publications has more than doubled since 1990, the number of research publications featuring one or more international coauthors has increased more than tenfold. ${ }^{27}$ There are several reasons behind this.

First, there is a growing recognition that many of the greatest challenges of our time are global in scope. Challenges like climate change, epidemics, international refugee crises, and cybersecurity do not respect international borders. It stands to reason that solutions to such grand challenges are most likely to be developed by

\footnotetext{
${ }^{24}$ Phi Delta Kappan (2017).

${ }^{25}$ Data from the Millennium Cohort Survey, accessed May 2018 at https://www.cls.ioe.ac.uk.

${ }^{26}$ Data from the Warwick Institute for Employment Research, The Longitudinal Survey, accessed May 2018 at https://warwick.ac.uk/fac/soc/ier/futuretrack.

${ }^{27}$ Bibliometrics data were accessed under licence from Clarivate Analytics, 2017. Analysis by the University of Toronto.
} 
research teams that are similarly global in scope, as well as interdisciplinary in composition.

Second, there is evidence to suggest that international collaboration often produces particularly innovative and influential results. The literature on creativity, collaboration, and innovation reminds us that heterogeneous teams are more likely to produce novel insights and breakthroughs, thanks to the wider range of ideas and perspectives on which they can draw.

Third, this claim is supported by bibliometric analysis, which confirms that international collaborations are especially fruitful and impactful. Internationally co-authored papers have been shown to have a higher citation impact than papers whose authorship is confined to a single country. ${ }^{28}$

For example, internationally co-authored papers accounted for just under half (48 per cent) of all publications produced by scholars at the University of Toronto between 2010 and 2016. These same publications account for more than four fifths ( 82 per cent) of the Highly Cited Publications ${ }^{29}$ attributed to authors affiliated with the University of Toronto. This same pattern is typical of other leading research universities around the world. For example, internationally co-authored papers represent 52 per cent of Oxbridge's publications, and 79 per cent of their Highly Cited Publications.

Solutions to today's grand challenges will not come from scholars working alone, jealously protecting their results. They are more likely to come from scholars collaborating with one another from around the globe, drawing on a global pool of ideas and discoveries.

Regarding international collaboration, I would suggest that universities need to do several things:

They must celebrate these international research partnerships and explain more clearly why they are important. They must help the wider public, as well as their government partners, appreciate their value by emphasising how our lives are improved by the ideas and discoveries developed through these global collaborations.

They must also celebrate the other ways in which the global reach of our universities benefits their host economies. Most obviously, universities are one of the primary channels through which talented human capital from around the world is attracted and retained locally - whether faculty, students, or recent graduates. In performing this function, universities enrich the talent pool of the cities and nations in which they are situated.

${ }^{28}$ See for example, Khor \& Yu (2016).

${ }^{29}$ 'Highly Cited Publications' as defined by Clarivate Analytics, 2017. 
By inviting the world to our cities and our campuses, as agents of cosmopolitanism, globally engaged universities foster fresh, new ideas, diverse perspectives and approaches that, in turn, generate breakthroughs in knowledge and innovation, and inspire deeper understanding.

The larger point here is that research universities connect their host regions to the world, and vice versa, in ways that bring important benefits to local communities. And these communities are more likely to recognise the value of international engagement because they are deeply embedded in it, from researchers and students to local cultural institutions and firms. In this way, universities can serve as potent forces combating rampant parochialism.

Intriguingly, the Brexit vote provided some revealing evidence to support this point. As one recent commentary observed, 'many feel the referendum vote was fueled by domestic concerns about immigration, yet many areas with a large proportion of international students voted to remain. ${ }^{30}$

\section{EMBRACING THE CITY-BUILDING MISSION}

Now onto my second strategy. Here I will argue that universities must embrace the mission of strengthening their host communities, economically and socially. My argument here is a simple one, and hardly original. By embracing city-building as an institutional priority, universities can do much to help themselves.

By deliberately taking on a civic role, universities will better position themselves to attract and inspire public support. After all, by marshalling their human and other resources in the service of improving quality of life for the residents of their host city-region, universities will be able to demonstrate visibly their concern for the well-being of their neighbours. As publicly supported institutions, they are quite naturally expected to take on such a role - though they are more often accused of shirking such responsibilities as they pursue ambitions of higher global profile and rankings.

Moreover, there is a clear case of enlightened self-interest at work here. The quality of the built and natural environment, the quality of public goods such as schools and parks, shorter commute times, cultural vitality, personal safety, and freedom from crime - these are all local attributes that help universities attract and retain talented faculty and staff (and recruit students). It stands to reason that the more universities can do to improve local quality of life, the more they will do to help themselves.

How is this to be achieved?

${ }^{30} \mathrm{QS} B \log$ (n.d.). 
A multidimensional approach would leverage the teaching, research, and outreach activities at the core of the university. Service learning and other forms of experiential learning bring a double pay-off of enriching our students' learning opportunities and enhancing their employability upon graduation, while also serving the needs of local communities. Research that addresses a city's most pressing challenges can lead to very significant advances of both a fundamental and an applied nature. Outreach and other forms of public service by our faculty and students can play a key role in elevating the level of debate and understanding of urban challenges. And doing this in a visible and deliberate way speaks volumes of the university's core values and commitments to social betterment.

As a geographer-president, the advantages to such a strategy are obvious to me. However, there are two well-established trends that may be working at cross purposes to this city-building agenda. In my view, both may require a serious rethink by university leadership.

\section{THE CHALLENGE OF ACCESS}

The first of these is the chronic challenge of ensuring access to higher education for students from lower income households and from under-represented groups, as noted earlier.

It is difficult to make the case that a university has seriously embraced its city-building mission if it remains (and is seen to be) a bastion of exclusion and privilege. As part of a city-building strategy, universities must redouble their efforts to promote access to higher education for students from the widest range of socio-economic backgrounds.

University leaders must do a better job of addressing the concerns of students and parents over the cost of higher education. We must make the real costs of attending our institutions lower, more transparent, and easier to understand-particularly for those who are currently under-represented on our campuses. This will require creative thinking and collaborating with our partners outside the academy.

We must also recruit students actively from those neighbourhoods that have historically been least likely to send their students to us. For many, the barriers to higher education are more than financial. The literature highlights the influence of non-financial barriers in dissuading low-income students from applying for admission in the first place.

One of the best predictors of whether or not a prospective student will attend university is if at least one of their parents attended university. Hence, it is doubly challenging to recruit so-called 'first-generation' students, an effort that requires 
specially tailored interventions to overcome psychological and behavioural impediments. Failure to address such factors is likely to perpetuate deeply engrained biases in university admissions.

As Foley and Green put it recently, 'if education policy is implemented in a way that perpetuates the income differences of the parents' generation among their children, more education ultimately could lead to more inequality. ${ }^{31}$ We need to redouble our efforts to extend opportunities to these chronically under-represented communities. $^{32}$

This is where our discussion of access to higher education and the university as city-builder intersects with wider trends towards income polarisation and the backlash against all things global.

After all, there is a large body of evidence documenting the lifelong and intergenerational benefits of access to higher education. If our institutions have failed to provide access to these benefits for all segments of society, then we may have been complicit in creating the conditions that have bred nativism and isolationism. This suggests the following hypothesis: that the failure of universities - and especially the more elite institutions - to move the needle significantly on access and socio-economic diversity is a major factor contributing not only to the declining esteem with which our institutions are regarded, but also to the parochial turn in national politics.

\section{OVERSEAS CAMPUSES: UNFORESEEN CONSEQUENCES?}

The second countervailing trend is the growing number of universities that have established branch campuses overseas.

According to a recent study, universities around the world have established 289 international branch campuses over the past two decades. Some 42 of them have since closed and another 22 are in the planning stages..$^{33}$

There are various reasons why a university might want to establish a branch campus in another country. Proponents most frequently cite international prestige as a primary motivation, pointing to the esteem that comes with being perceived as a global force in the education market. They may also be seeking financial return, trading on their foreign brand to attract students willing to pay high tuition fees.

\footnotetext{
${ }^{31}$ Foley \& Green (2015).

${ }^{32}$ Martin (2018) notes: 'Only 24 per cent of students in receipt of free school meals at age 15 make it to higher education by the age of 19, and in the South West and East Midlands the figure is just 15 per cent.'

${ }^{33}$ Cross-Border Education Research Team (2017).
} 
Following the initial flurry of activity fifteen to twenty years ago, when the first wave of overseas campuses was being set up, there has been considerable debate over the merits of such plans-perhaps not surprising, given the 15 per cent failure rate. Few international branch campuses remit funding back to their home jurisdiction; often, the flow is in the other direction. ${ }^{34}$ There are academic and political risks as well as financial ones.

My hypothesis here is that the establishment of an overseas campus weakens a university's local ties, and further undermines local confidence in its commitment to fostering local prosperity and economic opportunity.

The argument makes intuitive sense. Universities exert a propulsive effect on their local regions. They are stabilising forces, good for property values, magnets for global talent and investment, anchor tenants, and strong employers. Various studies attempt to quantify these factors. Universities UK has estimated the aggregate annual impact of universities at $£ 95$ billion to the UK economy in $2015 .{ }^{35}$ The University of Toronto estimates its annual impact at well over C $\$ 15$ billion to the Canadian economy. Most of this impact, of course, is felt at the local level.

Some 35 years ago, David Harvey famously characterised corporate managers as being locked in the perpetual search for more profitable locations elsewhere-in pursuit of what he called the 'spatial fix'. ${ }^{36}$ Traditionally, universities have been viewed as spatially embedded in their host communities, unlike private capital. Until quite recently, they have not deployed spatial mobility (or the 'spatial fix') as a competitive strategy. They were in it for the long haul. Communities recognised and valued this.

Indeed, one need only witness the lengths to which localities will go to attract a university when they do not already have one, to understand the value a university holds for its host urban region. When the Province of Ontario announced plans a few years ago to fund three new university campuses, dozens of municipalities and local stakeholders lined up as suitors.

Given all this, how do communities react when their local hero embarks on an international foray? Partnerships? Exchanges? Collaborations? By all means; these leave the host community and its institution stronger. But deploying scarce resources to start and operate an overseas branch, to achieve a measure of prestige that allegedly cannot be achieved at home, is a different matter.

If this general hypothesis is correct, then a recent article is surely worrisome. By suggesting that local universities ought to avail themselves of opportunities to reduce

\footnotetext{
${ }^{34}$ 'In addition to the transnational education revenue estimate of $£ 496$ million, the turnover of UK institutions' international branch campuses is estimated at $£ 140$ million for $2012 / 13$ but little of this is remitted to the UK due to their structural arrangements' (Mellors-Bourne et al. 2014: 12).

${ }^{35}$ Universities UK (2017b).

${ }^{36}$ Harvey (1982).
} 
costs by offshoring their labour-intensive services to branch campuses in lower-wage jurisdictions, this article extends the analogy to the corporate world even further. ${ }^{37}$ I will leave it to the reader to imagine the headlines for themselves.

My hypothesis, then, is that the trend towards opening international branch campuses is yet another factor undermining confidence in our institutions of higher education, owing to the perceived adverse impacts such activity may have on their home regions.

Moving towards conclusion, my argument is that the geographically informed strategy I have laid out here will help reposition higher education in a more favourable public light. The prescriptions I have suggested might go a considerable distance towards re-establishing confidence in the institutions of higher education - seriously recommitting to access and participation, strengthening and engaging our local communities, extending and recognising the power of local and global partnerships, broadening and deepening the pool of ideas and perspectives our students and faculty encounter.

\section{CODA: THE UNUSUAL CASE OF THE UNIVERSITY OF TORONTO}

I wish to conclude by suggesting that my own institution is something of an outlier on several of these issues.

For example, U of T's commitment to access and student financial aid is an integral part of the institution's identity. Our Policy on Student Financial Support, now twenty years old, formed the basis for the Province of Ontario's own recent policy reform. Our policy states that 'No student offered admission to a program at the University of Toronto should be unable to enter or complete the program due to lack of financial means. ${ }^{38}$

Drawing on both institutional and provincial financial aid (known as OSAP Ontario Student Assistance Program, our counterpart to Pell Grants), more than half of $U$ of T's full-time domestic undergrads receive needs-based financial aid. That is more than 26,000 students. Their average tuition is less than half the nominal ('sticker') price - that is, just over $\mathrm{C} \$ 4,000$, or a bit over $£ 2,300$. Roughly one quarter of our first-year, domestic undergraduate students are from families with incomes of $\$ 50,000$ or less - more than 13,000 students, almost the same number of first-year students enrolled in all the Ivy League universities combined.

\footnotetext{
${ }^{37}$ Moodie (2015).

${ }^{38}$ University of Toronto (1998).
} 
This commitment to access is part of an overall commitment to excellence in teaching and research. Harvard is the only university in the world to publish more peer-reviewed research than the University of Toronto. And our publications attract more citations than every other university in the world except for Harvard and Stanford. According to Times Higher Education, the University of Toronto is ranked 22nd in the world overall, and ninth among public universities. We have ably combined access with excellence.

How have we done this? There are many things I could point to. But let me single out two.

First, we have made scholarships one of our very highest priorities for fundraising. As a consequence, we have accumulated endowments to fund scholarships that now exceed C\$1 billion.

Second, we have embraced city-building as another institutional priority. We are leveraging our location in one of the world's most culturally diverse city-regions, for the benefit of both our university and the communities around us.

Our students take advantage of internships, service learning, and work-integrated learning opportunities on our doorstep to gain valuable experience and a leg-up in the job market following graduation. This may be one reason why they consistently rank so highly in the Times Higher Education Annual Employability Survey-our graduates are ranked 13th in the world, and fifth amongst graduates of the world's public universities.

Another key part of our city-building activity is our outreach. Last year, U of T dentistry students served 78,000 patient-visits in their clinic as part of their education and training. Half of these patients were children or seniors, and almost 90 per cent of them had no dental insurance. Similar outreach occurs in everything from law and engineering to music and physical education.

Finally, we recently established a new School of Cities to provide a focal point for research, teaching, and outreach related to tackling the most pressing challenges in urban regions. The School's mandate is avowedly applied, and it will work closely with external partners, both local and global. ${ }^{39}$

I have not recited all of these points just to brag. We certainly do not get everything right at the University of Toronto or in Ontario or in Canada. Not even close. We have a lot to learn from our friends in the UK and the US. And we are not immune to many of the same stresses and strains. Instead, I raise these points to argue that other models $d o$ exist, and probably deserve closer scrutiny. Nigel Thrift makes this point eloquently in his piece 'The University of Life' where he laments the 'lack of

\footnotetext{
${ }^{39}$ See http://www.schoolofcities.com.
} 
comparative analysis of [universities'] different institutional machineries and creeds that have often had very different relationships to state and economy and religion'. ${ }^{40}$

In any event, access and excellence need not be mutually exclusive - in fact, I have argued, they are complementary and mutually reinforcing. Nor should city-building be seen as coming at the expense of enhancing global reputation - to the contrary, global success rests on strong local foundations.

And I note that measures of confidence in universities, colleges, and higher education are significantly higher in Canada than they are in the US or UK. According to a 2017 survey, 78 per cent of Canadians have a positive overall view of Canadian universities. Only 3 per cent expressed a negative view. ${ }^{41}$

Similarly, Canada remains a champion of immigration and international engagement. In a 2018 survey by the Environics Institute for Survey Research, 60 per cent of Canadians disagreed that immigration levels are too high, and an extraordinary 80 per cent said immigrants have 'a positive economic impact' on the country. ${ }^{42}$

These Canadian views on higher education and immigration may change, of course. But for the moment, I cautiously draw two conclusions.

First, Canadians do not watch as much Fox News as their neighbours to the south.

And second, perhaps the geographical perspective I have offered here on the role universities can play in building a more prosperous and inclusive future is more than just theoretically compelling. Perhaps we have some evidence.

\section{Acknowledgements}

The author would like to acknowledge and thank Dr Tony Gray for his assistance in the preparation of this lecture. He is also grateful to Sir Nigel Thrift, FBA for his insightful comments on an earlier draft, and to Professor Felix Driver, FBA and Professor Neil Wrigley, FBA for their part in inviting me to give this Geography Lecture at the Academy.

\section{REFERENCES}

Allen, Katie (2016), 'Majority of Managers Think Brexit Uncertainty Will Affect UK Economy', The Guardian, 28 December 2016.

https://www.theguardian.com/business/2016/dec/28/majority-of-managers-think-brexit-uncertaintywill-affect-uk-economy

\footnotetext{
${ }^{40}$ Thrift (2016: 401).

${ }^{41}$ Anderson (2017).

${ }^{42}$ Environics Institute for Survey Research (2018).
} 
Anderson, Bruce (2017), 'Universities, Research \& Canadian Public Opinion', Abacus Data, 19 September (survey commissioned by Universities Canada). Accessed May 2018 at http://abacusdata.ca/universities-research-canadian-public-opinion/

Attwool, Jo (2017), 'Why The Sunday Times is Wrong on International Student Recruitment', Universities UK Blog, 7 August. Accessed May 2018 at https://www.universitiesuk.ac.uk/blog/Pages/sunday-times-wrong-international-student-recruitment.aspx

Auter, Zac (2017), 'What Gallup Learned About Higher Education in 2017', Gallup Blog, 27 December 27. Accessed May 2018 at http://news.gallup.com/opinion/gallup/224444/gallup-learned-higher-education-2017.aspx

Becker, Sascha O., Fetzer, Thiemo \& Novy, D. (2017), 'Who Voted for Brexit? A Comprehensive Districtlevel Analysis', CEP Discussion Paper No. 1480, London School of Economics, October. https://doi.org/10.1093/epolic/eix012

Bruni, Frank (2017), 'Higher Ed's Low Moment', The New York Times, 30 December. https://www.nytimes.com/2017/12/30/opinion/sunday/higher-eds-low-moment.html

Bryson, Bill (2015) The Road to Little Dribbling: More Notes from a Small Island (London, Doubleday).

Bureau of Labor Statistics (2018), 'Unemployment Rates and Earnings by Educational Attainment, 2017’, 27 March. https://www.bls.gov/emp/tables/unemployment-earnings-education.htm

Cross-Border Education Research Team (2017), C-BERT Branch Campus Listing, January [data originally collected by Kevin Kinser \& Jason E. Lane, SUNY Albany]. Accessed May 2018 at http://cbert.org/?page_id=34

Environics Institute for Survey Research (2018), 'Canadian Public Opinion about Immigration and Minority Groups', Winter 2018. Accessed May 2018 at

https://www.environicsinstitute.org/docs/default-source/project-documents/focus-canada-winter2018---immigration-and-minority-groups/focus-canada-winter-2018-survey-on-immigrationand-minority-groups---final-report.pdf?sfvrsn=ede94c5f_2

Fingerhut, Hannah (2017), 'Republicans Skeptical of Colleges' Impact on U.S., But Most See Benefits for Workforce Preparation', Factank, Pew Research Center, 20 July. Accessed May 2018 at http://www.pewresearch.org/fact-tank/2017/07/20/republicans-skeptical-of-colleges-impact-on-u-sbut-most-see-benefits-for-workforce-preparation/

Foley, Kelly \& Green, David (2015), 'Why More Education Will Not Solve Rising Inequality (And May Make It Worse)', Institute for Research on Public Policy; cited in Robson, Jennifer, 'PostSecondary Access - Transition Briefing: Better Life Chances for Ontario's Children', Ontario 360, School of Public Policy and Governance, University of Toronto.

Giles, Chris (2017), 'Brexit Uncertainty Hurting UK Economy, Says IMF', Financial Times, 20 December. https://www.ft.com/content/1615ddc2-36dc-3aea-b077-04657dfd0a56

Gilligan, Andrew (2017), 'Universities Take Foreign Students Ahead of British', The Sunday Times, 6 August.

https://www.thetimes.co.uk/article/universities-take-foreign-students-ahead-of-british-5nppfw5ks.

Harvey, David (1982), The Limits to Capital (Oxford, Blackwell).

ICEF Monitor (2018), 'Notable Growth in International Applications to British Universities This Year', 28 February. Accessed May 2018 at

http://monitor.icef.com/2018/02/notable-growth-international-applications-british-universities-year/

Jackson, Gavin, Tetlow, Gemma \& Khan, Mehreen (2017), 'Brexit Uncertainty is Holding Back Investment, Mark Carney Warns', Financial Times, 3 August. https://www.ft.com/content/23fd12b2-783b-11e7-90c0-90a9d1bc9691

Khor, K. A. \& Yu, L. G. (2016), 'Influence of International Co-authorship on the Research Citation Impact of Young Universities', Scientometrics, 107: 1095-110. https://doi.org/10.1007/s11192-016-1905-6 
Leonhardt, David (2017), 'The Assault on Colleges - and the American Dream', The New York Times, 25 May

https://www.nytimes.com/2017/05/25/opinion/sunday/the-assault-on-colleges-and-the-americandream.html

Martin, Iain (2018), 'Benchmarking Widening Participation: How Should We Measure and Report Progress?', Higher Education Policy Institute, Policy Note 6, April. Accessed May 2018 at http://www.hepi.ac.uk/wp-content/uploads/2018/04/HEPI-Policy-Note-6-Benchmarking-wideningparticipation-FINAL.pdf

Mellors-Bourne, Robin, Fielden, John, Kemp, Neil, Middlehurst, Robin \& Woodfield, Steve (2014), 'The Value of Transnational Education to the UK', BIS Research Paper Number 194, November, Department for Business, Innovation and Skills, London.

Millennium Cohort Survey, accessed May 2018 at https://www.cls.ioe.ac.uk

Moodie, Gavin (2015), 'Branching Out: Why Universities Open International Campuses Despite Little Reward', The Conversation, 11 October. Accessed May 2018 at https://theconversation.com/branching-out-why-universities-open-international-campuses-despite-littlereward-46129

Moody's Investors Service (2017), 'Moody's: US Higher Education Sector Outlook Revised to Negative as Revenue Growth Prospects Soften', 5 December. Accessed May 2018 at

https://www.moodys.com/research/Moodys-US-higher-education-sector-outlook-revised-to-negativeas--PR_376587

National Science Board (2018), Science \& Engineering Indicators 2018. Accessed May 2018 at https://www.nsf.gov/statistics/2018/nsb20181/

Neves, Jonathan \& Hillman, Nick (2017), '2017 Student Academic Experience Survey', Higher Education Academy and Higher Education Policy Institute. Accessed May 2018 at

http://www.hepi.ac.uk/wp-content/uploads/2017/06/2017-Student-Academic-Experience-SurveyFinal-Report.pdf

Okahana, Hironao \& Zhou, Enyu (2017), International Graduate Applications and Enrollment, Fall 2017, Council of Graduate Schools. Accessed May 2018 at

http://cgsnet.org/first-time-over-decade-international-graduate-applications-and-enrollments-decline-usinstitutions

Phi Delta Kappan (2017), 'The 49th Annual PDK Poll of the Public's Attitudes Toward the Public Schools', September 2017, V99 N1. Accessed May 2018 at http://pdkpoll.org/assets/downloads/PDKnational_poll_2017.pdf

QS Blog (n.d.), 'Which UK Universities Are Most Reliant on International Students?'. Accessed May 2018 at http://www.qs.com/which-uk-universities-are-most-reliant-on-international-students/

Saul, Stephanie (2018), 'As Flow of Foreign Students Wanes, U.S. Universities Feel the Sting', The New York Times, 2 January.

https://www.nytimes.com/2018/01/02/us/international-enrollment-drop.html

State Higher Education Executive Officers Association (2018), State Higher Education Finance: FY 2017. Accessed May 2018 at http://www.sheeo.org/sites/default/files/SHEF_FY2017.pdf

Tammes, Peter (2017), 'Investigating Differences in Brexit-vote Among Local Authorities in the UK: An Ecological Study on Migration- and Economy-related Issues', Sociological Research Online, September. https://doi.org/10.1177\%2F1360780417724067

Thrift, Nigel (2016), 'The University of Life', New Literary History 47(2 \& 3): 399-417. https://doi.org/10.1353/nlh.2016.0020

Toly, Noah (2016), 'Brexit, Global Cities, and the Future of World Order', Globalizations, 14(1): 142-9. https://doi.org/10.1080/14747731.2016.1233679 
Universities UK (2017a), 'The Economic Impact of International Students'. Accessed May 2018 at https://www.universitiesuk.ac.uk/policy-and-analysis/reports/Documents/2017/briefing-economicimpact-international-students.pdf

Universities UK (2017b), 'The Economic Impact of Universities in 2014-15'. Accessed May 2018 at https://www.universitiesuk.ac.uk/policy-and-analysis/reports/Documents/2017/the-economic-impactof-universities.pdf

University of Toronto (1998), Policy on Student Financial Support. Accessed May 2018 at http://www.governingcouncil.utoronto.ca/Assets/Governing+Council+Digital+Assets/ Policies/PDF/ppapr301998.pdf

Warwick Institute for Employment Research (2018), The Longitudinal Survey. Accessed May 2018 at https://warwick.ac.uk/fac/soc/ier/futuretrack

Zong, Jie \& Batalova, Jeanne (2018), 'International Students in the United States', Migration Policy Institute, May. Accessed May 2018,

https://www.migrationpolicy.org/article/international-students-united-states

Note on the Author: Meric Gertler CM FRSC FBA FAcSS is President of the University of Toronto and Professor of Geography and Planning. He is widely known for his work on the role of institutions in shaping innovation and local economic prosperity. His comparative analysis of urban economies spans North America, Europe, and Asia.

To cite the article: Meric S. Gertler (2018), 'Higher education in turbulent times: A geographical perspective', Journal of the British Academy, 6: 239-258.

DOI https://doi.org/10.5871/jba/006.239

This article is licensed under a

Creative Commons Attribution-NonCommercial-NoDerivs 3.0 Unported License.

Journal of the British Academy (ISSN 2052-7217) is published by

The British Academy - the national academy for the humanities and social sciences.

10-11 Carlton House Terrace, London, SW1Y 5AH

www.britishacademy.ac.uk 